\title{
A New Area to Fight: Electronic Cigarette
}

\section{Şermin Börekçi ${ }^{1}$, Nazmi Bilir² ${ }^{2}$ Celal Karlıkaya ${ }^{3}$, TUSAD Tobacco Working Group ${ }^{4}$}

\author{
${ }^{1}$ Department of Chest Diseases, İstanbul University Cerrahpaşa Faculty of Medicine, İstanbul \\ ${ }^{2}$ Hacettepe University, Institute of Public Health, Ankara \\ ${ }^{3}$ Clinic of Chest Diseases, Medicalpark Hospital, İstanbul \\ ${ }^{4}$ Turkish Respiratory Society Tobacco Working Group
}

\begin{abstract}
Electronic cigarette (e-cigarette) is spreading like an epidemic that threatens the public health. Last one year, e-cigarette use increased by 2 times in both adults and children, and just as the cigarette ads of 1950s and 1960s, e-cigarette ads are taking place in the television, radio, internet, magazines and in the all kinds of advertising media. E-sigara should be recognized as a serious health threat, and should be fought against it. The aim of this review is to show the effects of e-cigarette on health by the scientific evidences.
\end{abstract}

Keywords: Effects on health, electronic cigarettes, the fight against tobacco

Received Date: 22.10.2014 Accepted Date: 02.01.2015

Address for correspondence Şermin Börekçi

E-mail: serminborekci@yahoo.com.tr

This work is licensed under a Creative Commons Attribution-NonCommerci 4.0 International License.

DOI: $10.5152 /$ ejp.2015.65375

-Available online at www.eurasianjpulmonol.com

\section{INTRODUCTION}

Turkey has been one of the countries implementing the most effective tobacco control in the world with its successful and decisive studies over the past 15-20 years, and it is also the first and only country applying the criteria of MPOWER (the criteria of Monitor, Protect, Offer, Warn, Enforce, and Raise) at the highest level. In accordance with the Report of Global Adult Tobacco Survey 2012, 27.2\% of individuals older than 15 years are smokers in Turkey (1). The general tactic of the tobacco industry against the successful anti-smoking interventions in the world and in our country has been to find various alternative ways to encourage smoking. The main bases of promotion strategies include the development of more attractive products for people who have never tried smoking before and more distracting products for the ones thinking to quit smoking (for instance, products thought to be less harmful), and also to make smokers more addicted (2). The most important method used by tobacco companies is to try to increase consumption by "decreasing the harms" and to create political pressure for enabling products that will be produced for this aim to be allowed. In this regard, the design and sale of electronic cigarettes (e-cigarettes) have spread like an epidemic that threatens public health. In the last year, the use of e-cigarettes by both adults and children has increased 2-fold. As in the tobacco advertisements in the 1950s and 1960s, the promotion of e-cigarettes is done in the television, radio, internet, magazines and all advertising media, and companies try to convince people about the harmlessness of e-cigarettes $(3,4)$.

The invention of the e-cigarette dates back to 1963. It has a mechanism where it works with electric power and vaporizes the liquid, and its use is similar to smoking. It comprises a replaceable cartridge full of liquid in a stick with the same length of a real cigarette or a bit longer. This cartridge essentially contains nicotine and propylene glycol. When air passes through the stick, the microprocessor system powered by a battery activates, and micron-sized particles from the liquid in the cartridge are sprayed into the passing air. The vapor is inhaled by the person, and it is delivered to the lungs. Nicotine is taken in this way. Propylene glycol contained in the liquid in the cartridge creates a scent similar to that of cigarette smoke. The microprocessor running on a battery also activates a red-orange colored light 
(light-emitting diode) at the end of the stick. When it lights up, a temperature of approximately $50-60^{\circ} \mathrm{C}$ is reached, which heats nicotine and thus provides the same sensation as a real cigarette. The battery and cartridge can be replaced when necessary. There are forms of cigar and pipe that work with the same mechanism. The amount of nicotine contained in the product can vary between 0.1 and $30 \mu \mathrm{g}$ per inhalation. The amounts of other substances (propylene glycol, tobacco essence, glycerin, organic acid, citric acid, alcohol, water, and other agents) as well as nicotine also differ $(3,5,6)$. Different flavors such as tobacco, fruit, mint, chocolate, coffee, and coke can be added into the liquid in the cartridge, or a specific cigarette brand can be imitated. Flavoring agents rather than menthol in e-cigarettes have been banned to decrease the attention of children and the young in the United States of America (USA) (7).

The device was first introduced to the Chinese market as a method for smoking cessation in 2004. By 2005 and 2006, China began to export the device, and it gained a place in the markets of different countries. However, the quality control test for the device has not been adequately performed. It was found that users can modify it for using addictive substances such as hashish $(8,9)$.

In our country, e-cigarettes were sold to people through both media and direct marketing techniques (including door-to-door selling) in spite of them not being a proven product in 2007 and 2008. With the efforts of the Department of Struggle with Cancer at the Ministry of Health, the promotion, formal sale, and marketing of this product were restricted, and people were informed that it was not a medical product. Until 2013, there was no law banning e-cigarettes in Turkey, but only a circular letter was issued by the Ministry of Health (10). With the amendments to the Law No.4207 passed in 2013, e-cigarettes were included in this law, and it was banned to promote them, smoke them indoors, and sell them young persons under the age of $18(11,12)$. Similarly, bans on e-cigarettes are imposed in developed countries such as USA and Canada (13).

Society-based studies show that e-cigarettes are more frequently used by people who still smoke (dual use), then by people who have quit smoking, and less frequently by people who have never smoked (14-16). Although data for adolescents are less, it is known that the dual use of e-cigarettes and conventional cigarettes is common among them. The results show that the rate of the use of e-cigarettes increases 3 -fold faster in adolescents than in adults $(14,17)$. Indeed, some of the young people, who do not smoke conventional cigarettes but have tried e-cigarettes, continue to use e-cigarettes and have become addicted to nicotine. All these demonstrate the extent of the harmful effects of e-cigarettes on health.

The use of e-cigarettes contrast the two main principles of tobacco control: the first is the fight against nicotine addiction. Because people who use e-cigarettes still take nicotine, it is not possible to remove nicotine addiction. The second principle is to avoid behaviors that give a reminder of smoking. The users of e-cigarettes show behaviors related to smoking (getting a cigarette from the pack, inhaling the smoke, etc.) The continuance of these behaviors indicates the continuance of smoking habit. However, Etter and Bullen (18) selected people who had quit smoking and had just begun to use e-cigarettes from the web site of e-cigarettes and followed them for one year. They found in that $6 \%$ of people began to smoke again and that $92 \%$ continued to use e-cigarettes every day. Based on these re- sults, the authors suggested that e-cigarettes could prevent relapses. Because existing evidence is inadequate for the reliability of e-cigarettes, they have not been approved by any health institution for smoking cessation treatment till now.

The effects of an e-cigarette on health can be examined under the following headings in accordance with literature:

1. Toxic Chemical Substances It Contains

2. Cytotoxicity

3. Passive Smoke Exposure

4. Difficulty in Controlling Nicotine Absorption

5. Its Proven Harmful Effects on Health

6. Its Effects on Smoking Cessation

\section{Toxic Chemical Substances it Contains}

Studies show that an e-cigarette contains many toxic and carcinogenic substances. Goniewicz et al. (19) revealed that toxic substances contained in a conventional cigarette are also contained in the smoke inhaled from an e-cigarette (Table 1). As shown in the table, some substances not contained in a cigarette are contained in an e-cigarette. Kim and Shin (20) found that of carcinogenic nitrosamines specific to tobacco, nitrosonornicotine, 4-(nitrosomethylamino)-1-(3-pyridyl)-butanone, and nitrosoanatabine are also contained in an e-cigarette.

The proven toxic and carcinogenic content of an e-cigarette conflicts the claim that "it is harmless," which is mentioned in its promotion.

\section{Cytotoxicity}

The vapor of an e-cigarette shows toxic effect on the cells because of its harmful content. In the study by Bahl et al. (21), it was revealed that flavoring agents apart from nicotine lead to cytotoxic effects on human embryo stem cells, rat neural stem cells, and less frequently, human pulmonary fibroblasts. The fact that embryo stem cells are more sensitive to the vapor released from an e-cigarette compared

Table 1. Toxic substances contained in an e-cigarette and its comparison with a conventional cigarette (adapted from 19)

\begin{tabular}{|c|c|c|}
\hline Toxic substance & $\begin{array}{l}\text { The mean for person } \\
\text { inhaling } 15 \text { times } \\
\text { from } 12 \text { different } \\
\text { brands of e-cigarettes }\end{array}$ & $\begin{array}{l}\text { The mean in } \\
\text { the mainstream } \\
\text { smoke of a } \\
\text { cigarette }\end{array}$ \\
\hline Formaldehyde, $\mu \mathrm{g}$ & $0.2-5.61$ & $1.6-52$ \\
\hline Acetaldehyde, $\mu \mathrm{g}$ & $0.11-1.36$ & $52-140$ \\
\hline Acrolein, $\mu \mathrm{g}$ & $0.07-4.19$ & $2.4-62$ \\
\hline $\begin{array}{l}\text { o-Methylbenzaldehyde, } \\
\mu \mathrm{g}\end{array}$ & $0.13-0.71$ & $\ldots$. \\
\hline Toluene, $\mu \mathrm{g}$ & $0.0-0.63$ & $8.3-70$ \\
\hline $\mathrm{p}$-, m-Xylene, $\mu \mathrm{g}$ & $0.0-0.2$ & $\cdots$ \\
\hline NNN, ng & $0.0-0.00043$ & $0.005-0.19$ \\
\hline NNK, ng & $0.00-0.0283$ & $0.012-0.11$ \\
\hline Cadmium, ng & $0.0-0.022$ & $\ldots$ \\
\hline Nickel, ng & $0.011-0.029$ & $\cdots$ \\
\hline Lead, ng & $0.003-0.057$ & $\ldots$ \\
\hline
\end{tabular}

NNK: 4-(nitrosomethylamino)-1-(3-pyridyl)-butanone; NNN: nitrosonornicotine 
with adult pulmonary fibroblasts has contributed to an increased awareness of the possible harms of e-cigarettes, particularly in pregnant females or people passively exposed to smoke. Farsalinos et al. (22) found that toxicity on rat heart myoblast cells exposed to the vapor of e-cigarette containing various additives is most likely caused by the vapor of e-cigarette with the flavor of tobacco and cinnamon. The severity of the toxic effects of e-cigarettes can vary depending on the types and amounts of additives in it, which can result in serious outcomes.

\section{Passive Smoke Exposure}

It is doubtful if e-cigarettes do not lead to passive smoke exposure because it does not burn and release sidestream smoke to the environment. Schober et al. (23) conducted a study for investigating indoor air quality in association with the use of e-cigarettes and detected seven polyaromatic hydrocarbons (included in group 1, group $2 \mathrm{~A}$, group $2 \mathrm{~B}$, and group 3 carcinogenic substances) classified as carcinogenic substances by the International Agency for Research on Cancer, a high level of nicotine, propane-1-2-diol, glycerin, and aluminum (group 1 carcinogenic). Similarly, Schripp et al. (24) reported that formaldehyde, acetaldehyde, isoprene, acetic acid (at different levels depending on the brand), 2-butanedione, acetone, propanol, propylene glycol, diacetin released from aromatizing additives, aromatic oils, and nicotine spread around from the vapor that emerged during the use of e-cigarette. Flouris et al. (25) found that the level of serum cotinine is similar in people passively exposed to conventional cigarette smoke and e-cigarette vapor $(0.8 \mathrm{ng} / \mathrm{mL}$ for conventional cigarette, $0.5 \mathrm{ng} / \mathrm{mL}$ for e-cigarette). Czogala et al. (26) stated that both cigarette smoke and e-cigarette vapor contains thin particles (PM 2.5) but that the density of these particles is lower in e-cigarettes. There is strong evidence that exposure to thin or very thin particles in the short or long term can lead to inflammatory events in all systems, particularly in the respiratory system, and increase cardiovascular system diseases, respiratory tract diseases, and the risk of death (27-30). On the other hand, Fuoco et al. (31) revealed that the distribution of particles in e-cigarette vapor is similar to that in normal cigarette smoke and that the amount of particles is directly proportional to the amount of nicotine in the liquid and the exposure time. The study by Zhang et al. (32) examining the distribution of thin particles released from e-cigarettes in the human body is one of the major studies conducted on this topic. In this study, it was shown that approximately $20-27 \%$ of particles in e-cigarette vapor accumulate in the circulatory system and also in all organs, which is comparable to the rate of $25-35 \%$ in a conventional cigarette.

In e-cigarettes, 2-100-fold polyfill fibers, including heavy metals such as nickel, copper, iron, and chrome, are used for heating and vaporizing the liquid. Nanoparticles of nickel and chromium emerge after the heating process. These nanoparticles accumulate in the alveoli and results in regional toxicity. They then enter the systemic circulation (3).

All these studies prove that the amount and distribution of toxic particles in the content of vapor released during the use of e-cigarettes are similar to those in the content of cigarette smoke. In a closed area where an e-cigarette is used, these particles are available in the air, and they cause passive smoke exposure.

Unlike the smoke of conventional cigarettes, the vapor of e-cigarettes does not contain carbon monoxide.

\section{Difficulty in Controlling Nicotine Absorption}

Studies have shown that an e-cigarette can provide an equal amount of nicotine as a conventional cigarette does and that users can change the number of e-cigarettes according to their habits and increase their number of use (33-36). Hence, it was found that blood cotinine levels of e-cigarette and cigarette users are similar (20 ng/ $\mathrm{mL}$ in average) (25). Bullen et al. (33) stated in their study that one of three e-cigarette devices malfunctioned and did not provide adequate nicotine. This suggests that the dose reliability of e-cigarettes has not yet been ensured.

\section{Its Proven Harmful Effects on Health}

The liquid used in an e-cigarette contains glycerin and propylene glycol, which have been proven to be toxic. Propylene glycol is a substance that can lead to irritation in the eyes and other mucosae and show toxic effects on all systems on repeated exposure (37). Its use has been banned in many areas because of its existent effects (38, 39). Propylene glycol converts into glycogen oxide, which is classified in the Group 2B carcinogenic group by the International Agency for Research on Cancer, after the heating and vaporizing processes. Similarly, glycerin converts into glycerol and then into acrolein, which causes upper respiratory tract irritation (40-42). Vardavas et al. (43) found that the results of spirometry performed after the use of e-cigarette for $5 \mathrm{~min}$ in healthy smokers are normal but that there is a significant increase in the dynamic airway resistance $(p=0.024)$ and a decrease in the level of exhaled nitric oxide $(16 \%, p=0.005)$. The increased airway resistance probably results from the irritation effect of propylene glycol in an e-cigarette and constriction in the peripheral airways. Decreased levels of nitric oxide can be due to oxidative stress. The most common side effects of e-cigarette use are irritation of oral and throat mucosae, cough, nausea, and vomiting. In addition, life-threatening effects such as pneumonia, heart failure, and hypotension have been reported (44).

Some users can get injured because of the explosion of the e-cigarette device $(45,46)$. There are a few studies about the harms of e-cigarette on health. The studies conducted are mostly about the biological effects occurring after short-term exposure to the vapor of e-cigarette. It is still early to investigate the effects of long-term use.

\section{Its Effects on Smoking Cessation}

Companies plan to increase the sales by informing consumers that e-cigarettes can be used for smoking cessation. There are significant and remarkable studies including five society-based studies (four long-term, one cross-sectional) and four clinical trials that were recently conducted on this topic. The conclusion derived from all these studies is that e-cigarettes are not useful for smoking cessation. These studies are briefly mentioned below.

Adkison et al. (47) conducted a study including people from USA, Canada, United Kingdom, and Austria, and they found no difference between smokers who used e-cigarettes for the aim of smoking cessation and ones who used them without this aim with regard to the rates of smoking cessation 1-year later $(p=0.52)$. On the other hand, in the study of Vickerman et al. (48), the rate of smoking cessation was found to be statistically lower in people using e-cigarettes than that in people not using e-cigarettes $(p<0.001)$. This result is an indicator that e-cigarettes will cause the continuance of nicotine addiction and negatively affect smoking cessation. In the study by Grana 
et al. (49) conducted in 2014, no difference was observed in terms of the rates of smoking cessation between smokers using and not using e-cigarettes $(\mathrm{OR}=0.76 ; 95 \% \mathrm{Cl}=0.36-1.60)$. Similarly, Choi and Foster (50) revealed that the use of e-cigarettes is not effective for smoking cessation $(p=0.93)$. Additionally, in an international cross-sectional study, it was found that e-cigarettes were not useful to quit smoking $(\mathrm{OR}=0.61,95 \% \mathrm{Cl}=0.45-0.83)(51)$.

In 3 of the 4 existing studies investigating the effect of e-cigarettes on smoking cessation, there was no control group (52-54). In the fourth study, the efficiency of e-cigarette was compared with $21 \mathrm{mg}$ nicotine patch treatment (55). Of these studies, in the study by Polosa et al. (52), only 5 of 40 people could quit smoking in the second year (12.5\%). This rate was $14.3 \%$ ( 2 of 14 patients) in the study conducted by Caponnetto et al. (53). In another randomized controlled study of Caponetto et al. (54), no difference was observed with regard to the rates of smoking cessation between people using and not using e-cigarettes. Bullen et al. (55) compared e-cigarette and nicotine patch in their study and found no significant difference between the groups. On the other hand, some authors suggest that e-cigarettes can be used for supporting the treatment for smoking cessation in patients chosen among the ones who have treatment failure in their history and who do not want to use the present treatment for smoking cessation.

The general conclusion of all these studies is that e-cigarettes are not effective in smoking cessation.

The American Heart Association has stated in their declaration that the sale and use of e-cigarettes must be involved in the laws together with other products, including tobacco, and that its sale to young children must be forbidden (56). Furthermore, the World Health Organization (WHO) presented its detailed report on e-cigarettes in the conference conducted in Moscow with the participation of many countries and explained existing and possible harms of e-cigarettes in this report (57). Following this report, the WHO has published another report emphasizing the necessity of taking strict control measures regarding the sale and use of e-cigarette (58).

\section{CONCLUSION}

In conclusion, e-cigarettes threaten public health because of the substances they contain. Hereafter, the fight against e-cigarettes should be another issue in the struggle with tobacco. Society should be informed about the harms of e-cigarettes, and awareness should be raised by political authorities for taking necessary precautions.

Peer-review: Externally peer-reviewed.

Author contributions: Concept - Ş.B., N.B., C.K., Tusad Tobacco Working Group; Design - Ş.B., N.B., C.K., Tusad Tobacco Working Group; Supervision - Ş.B., N.B., C.K., Tusad Tobacco Working Group; Resource - Ş.B., N.B., C.K., Tusad Tobacco Working Group; Materials - Ş.B., N.B., C.K., Tusad Tobacco Working Group; Data Collection and/or Processing - Ş.B., N.B., C.K., Tusad Tobacco Working Group; Analysis and/or Interpretation - Ş.B., N.B., C.K., Tusad Tobacco Working Group; Literature Search - Ş.B., N.B., C.K., Tusad Tobacco Working Group; Writing - Ş.B., N.B., C.K.; Critical Reviews - Ş.B., N.B., C.K., Tusad Tobacco Working Group; Other - S..B., N.B., C.K., Tusad Tobacco Working Group.

Conflict of Interest: No conflict of interest was declared by the authors.

Financial Disclosure: The authors declared that this study has received no financial support.

\section{REFERENCES}

1. Türkiye İstatistik Kurumu Küresel Yetişkin Tütün Araştırması Raporu 2012. Haber Bülteni, Sayı: 13142, 31/08/2012. Available from: http://www.tuik. gov.tr/PreHaberBultenleri.do?id=13142.

2. Gültekin Karakaş D. Türkiye Tütün Sektöründe Piyasa-Yönelimli Dönüşüm. Turk Toraks Derg 2014; 15: 71-91.

3. Grana R, Benowitz N, Glantz SA. E-cigarettes: a scientific review. Circulation 2014; 129: 1972-86. [CrossRef]

4. Felberbaum M. Old Tobacco Playbook Gets New Use by E-Cigarettes. The Associated Press. 2013. Available from: http://finance.yahoo.com/news/ old-tobacco-playbook-gets-e-125912186.html- gets-new-use-e-cigarettes. Accessed May 21, 2014.

5. Bilir N. Elektronik sigara-tütün kontrolünde yeri var mı. Tütün ve Alkol Piyasası Düzenleme Kurulu, Belgeler, 0cak 2008.

6. Grana RA, Ling PM. "Smoking revolution": a content analysis of electronic cigarette retail websites. Am J Prev Med 2014; 46: 395-403. [CrossRef]

7. US Department of Health and Human Services. Preventing tobacco use among youth and young adults: a report of the Surgeon General. Atlanta, GA: U.S. Department of Health and Human Services, Centers for Disease Prevention and Control, National Center for Chronic Disease Prevention and Health Promotion, Office on Smoking and Health; 2012.

8. Trtchounian A, Talbot P. Electronic nicotine delivery systems: is there a need for regulation? Tob Control 2011; 20: 47-52. [CrossRef]

9. Givens A, Cheng P-S. I-Team: E-cigarettes, used to smoke marijuana, spark new concerns. 4 New York. October 11, 2013. Available from: http://www.nbcnewyork.com/investigations/ECigarettes-Drugs-Marijuana-Vapor-Pens-Smoking-I-Team-227269001.html. Accessed May 19, 2014.

10. Sağlık Bakanlığı Illaç ve Eczacılık Genel Müdürlüğü'nün B10.0.IEG.0.13.00.14-312-04 sayılı elektronik sigara hakkındaki genelgesi, 2008. Available from: http://www.istanbuleczaciodasi.org.tr/?page=duyurular\&anns_ID $=1168$.

11. Elektronik Sigara ve Olası Sağlık Riskleri. Available from: http://www. kanser.gov.tr/Dosya/Bilgi-Dokumanlari/raporlar/e-sigara.pdf: T.C. Sağlık Bakanlığı Kanser Savaş Daire Başkanlığı.

12. 11.06 .2013 tarih ve 28674 sayılı Resmi Gazete'de yayımlanarak yürürlüğe giren 4207 sayılı Tütün Ürünlerinin Zararlarının Önlenmesi ve Kontrolü Hakkında Kanun değişikliği. Available from: http://www.resmigazete. gov.tr/eskiler/2013/06/20130611-1.htm. Acccessed 14 September 2014.

13. Miller A. E-cigarette debate divides regulators and consumers. CMAJ 2014; 186: 169-70. [CrossRef]

14. King BA, Alam S, Promoff G, Arrazola R, Dube SR. Awareness and ever-use of electronic cigarettes among U.S. adults, 2010-2011. Nicotine Tob Res 2013; 15: 1623-7. [CrossRef]

15. Dockrell M, Morrison R, Bauld L, McNeill A. E-cigarettes: prevalence and attitudes in Great Britain. Nicotine Tob Res 2013; 15: 1737-44. [CrossRef]

16. Choi K, Forster JL. Beliefs and experimentation with electronic cigarettes: a prospective analysis among young adults. Am J Prev Med 2014; 46: 175-8. [CrossRef]

17. Centers for Disease Control and Prevention (CDC). Notes from the field: electronic cigarette use among middle and high school students - United States, 2011-2012. MMWR Morb Mortal Wkly Rep 2013; 62: 729-30.

18. Etter JF, Bullen C. A longitudinal study of electronic cigarette users. Addict Behav 2014; 39: 491-4. [CrossRef]

19. Goniewicz ML, Knysak J, Gawron M, Kosmider L, Sobczak A, Kurek J, et al. Levels of selected carcinogens and toxicants in vapour from electronic cigarettes. Tob Control 2014; 23: 133-9. [CrossRef]

20. Kim HJ, Shin HS. Determination of tobacco-specific nitrosamines in replacement liquids of electronic cigarettes by liquid chromatography-tandem mass spectrometry. J Chromatogr A 2013; 1291: 48-55. [CrossRef]

21. Bahl V, Lin S, Xu N, Davis B, Wang YH, Talbot P. Comparison of electronic cigarette refill fluid cytotoxicity using embryonic and adult models. Reprod Toxicol 2012; 34: 529-37. [CrossRef]

22. Farsalinos KE, Romagna G, Allifranchini E, Ripamonti E, Bocchietto E, Todeschi S, et al. Comparison of the cytotoxic potential of cigarette smoke 
and electronic cigarette vapour extract on cultured myocardial cells. Int J Environ Res Public Health 2013; 10: 5146-62. [CrossRef]

23. Schober W, Szendrei K, Matzen W, Osiander-Fuchs H, Heitmann D, Schettgen $\mathrm{T}$, et al. Use of electronic cigarettes ( e-cigarettes) impairs indoor air quality and increases FeNO levels of e-cigarette consumers. Int J Hyg Environ Health 2014; 217: 628-37. [CrossRef]

24. Schripp T, Markewitz D, Uhde E, Salthammer T. Does e-cigarette consumption cause passive vaping? Indoor Air 2013; 23: 25-31. [CrossRef]

25. Flouris AD, Chorti MS, Poulianiti KP, Jamurtas AZ, Kostikas K, Tzatzarakis MN, et al. Acute impact of active and passive electronic cigarette smoking on serum cotinine and lung function. Inhal Toxicol 2013; 25: 91-101. [CrossRef]

26. Czogala J, Goniewicz ML, Fidelus B, Zielinska-Danch W, Travers MJ, Sobczak A. Secondhand exposure to vapors from electronic cigarettes. Nicotine Tob Res 2014; 16: 655-62. [CrossRef]

27. Secondhand Smoke Exposure and Cardiovascular Effects: Making Sense of the Evidence. Washington, DC: Institute of Medicine; 2010.

28. Brook RD, Rajagopalan S, Pope CA, Brook JR, Bhatnagar A, Diez-Roux AV et al. Particulate matter air pollution and cardiovascular disease: an update to the scientific statement from the American Heart Association. Circulation 2010; 121: 2331-78. [CrossRef]

29. Pope CA 3rd, Burnett RT, Krewski D, Jerrett M, Shi Y, Calle EE, et al. Cardiovascular mortality and exposure to airborne fine particulate matter and cigarette smoke: shape of the exposure-response relationship. Circulation 2009; 120: 941-8. [CrossRef]

30. Mehta S, Shin H, Burnett R, North T, Cohen AJ. Ambient particulate air pollution and acute lower respiratory infections: a systematic review and implications for estimating the global burden of disease. Air Qual Atmos Health 2013; 6: 69-83. [CrossRef]

31. Fuoco FC, Buonanno G, Stabile L, Vigo P. Influential parameters on particle concentration and size distribution in the mainstream of e-cigarettes. Environ Pollut 2014; 184: 523-9. [CrossRef]

32. Zhang Y, Sumner W, Chen DR. In vitro particle size distributions in electronic and conventional cigarette aerosols suggest comparable deposition patterns. Nicotine Tob Res 2013; 15: 501-8. [CrossRef]

33. Bullen C, McRobbie H, Thornley S, Glover M, Lin R, Laugesen M. Effect of an electronic nicotine delivery device (e cigarette) on desire to smoke and withdrawal, user preferences and nicotine delivery: randomized cross-over trial. Tob Control 2010; 19: 98-103. [CrossRef]

34. Etter JF, Bullen C. Saliva cotinine levels in users of electronic cigarettes. Eur Respir J 2011; 38: 1219-20. [CrossRef]

35. Vansickel AR, Eissenberg T. Electronic cigarettes: effective nicotine delivery after acute administration. Nicotine Tob Res 2013; 15: 267-70. [CrossRef]

36. Dawkins L, Corcoran O. Acute electronic cigarette use: nicotine delivery and subjective effects in regular users. Psychopharmacology 2014; 231: 401-7. [CrossRef]

37. Sciencelab.com, Inc. Material Data Safety Sheet: Propylene Glycol. Updated May 21, 2013. Sciencelab.com, Inc., Houston, TX. Accessed May 22, 2014.

38. Dow Chemical Co. Product Safety Assessment (PSA): propylene glycol. 2013. Available from: http://www.dow.com/productsafety/finder/prog. htm\#HealthInfo. Accessed May 22, 2014.

39. American Chemistry Council (2003) Ethylene Glycols: Considerations Against Use in Theatrical Fogs/Mist and Artificial Smoke. Available from: http://www.americanchemistry.com/ProductsTechnology/Ethylene-Glycols-2/PDF-ethylene-Glycols-Fog-Information-Sheet.pdf, Accessed 22 May 2014.

40. Laino T, Tuma C, Moor P, Martin E, Stolz S, Curioni A. Mechanisms of propylene glycol and triacetin pyrolysis. J Phys Chem A 2012; 116: 4602-9. [CrossRef]
41. US Environmental Protection Agency. Acrolein. Available from: http:// www.epa.gov/ttnatw01/hlthef/acrolein.html. Accessed May 22, 2014.

42. Henderson TR, Clark CR, Marshall TC, Hanson RL, CH H. Heat degradation studies of solar heat transfer fluids Solar Energy 1981; 27: 121-8. [CrossRef]

43. Vardavas $\mathrm{Cl}$, Anagnostopoulos N, Kougias M, Evangelopoulou V, Connolly GN, Behrakis PK. Short-term pulmonary effects of using an electronic cigarette: impact on respiratory flow resistance, impedance, and exhaled nitric oxide. Chest 2012; 141: 1400-6. [CrossRef]

44. Chen IL. FDA summary of adverse events on electronic cigarettes. Nicotine Tob Res 2013; 15: 615-6. [CrossRef]

45. CBS News. Electronic cigarette explodes in man's mouth, causes serious injuries. February 16, 2012. Available from: http://www.cbsnews.com/ news/electroniccigarette-explodes-in-mans-mouth-causes-serious-injuries/. Accessed May 23, 2014.

46. Strickland J. Woman says e-cigarette exploded, shot flames 4 feet across living room. WSB-TV Atlanta. 2013. Available from: http://www.wsbtv. $\mathrm{com} /$ news/news/local/woman-says-e-cigarette-exploded-shot-flames-4-feet/nZkCX/. Accessed May 23, 2014.

47. Adkison SE, O'Connor RJ, Bansal-Travers M, Hyland A, Borland R, Yong $\mathrm{HH}$, et al. Electronic nicotine delivery systems: international tobacco control four-country survey. Am J Prev Med 2013; 44: 207-15. [CrossRef]

48. Vickerman KA, Carpenter KM, Altman T, Nash CM, Zbikowski SM. Use of electronic cigarettes among state tobacco cessation quitline callers. $\mathrm{Ni}$ cotine Tob Res 2013; 15: 1787-91. [CrossRef]

49. Grana R, Popova L, Ling PM. A longitudinal analysis of electronic cigarette use and smoking cessation. JAMA Intern Med 2014; 174: 812-3. [CrossRef]

50. Choi K, Forster JL. Beliefs and experimentation with electronic cigarettes: a prospective analysis among young adults. Am J Prev Med 2014; 46 : 175-8. [CrossRef]

51. Popova L, Ling PM. Alternative tobacco product use and smoking cessation: a national study. Am J Public Health 2013; 103: 923-30. [CrossRef]

52. Polosa R, Caponnetto P, Morjaria JB, Papale G, Campagna D, Russo C. Effect of an electronic nicotine delivery device (e-cigarette) on smoking reduction and cessation: a prospective 6-month pilot study. BMC Public Health 2011; 11: 786. [CrossRef]

53. Caponnetto P, Auditore R, Russo C, Cappello GC, Polosa R. Impact of an electronic cigarette on smoking reduction and cessation in schizophrenic smokers: a prospective 12-month pilot study. Int J Environ Res Public Health 2013; 10: 446-61. [CrossRef]

54. Caponnetto P, Campagna D, Cibella F, Morjaria JB, Caruso M, Russo C, et al. EffiCiency and Safety of an eLectronic cigAreTte (ECLAT) as tobacco cigarettes substitute: a prospective 12-month randomized control design study. PLoS One 2013; 8: e66317. [CrossRef]

55. Bullen C, Howe C, Laugesen M, McRobbie H, Parag V, Williman J, et al. Electronic cigarettes for smoking cessation: a randomised controlled trial. Lancet 2013; 382: 1629-37. [CrossRef]

56. Bhatnagar A, Whitsel LP, Ribisl KM, Bullen C, Chaloupka F, Piano MR, et al. Electronic Cigarettes: a policy statement from the American Heart Association. Circulation 2014; 130: 1418-36. [CrossRef]

57. Electronic nicotine delivery systems. Conference of the Parties to the WHO Framework Convention on Tobacco Control. Sixth session Moscow, Russian Federation,13-18 October 2014. Provisional agenda item 4.4.2. Available from: http://www.who.int/fctc/cop/en/. Accessed September 14, 2014.

58. World Health Organization (WHO). Backgrounder on WHO report on regulation of e-cigarettes and similar products. Available from: http:// www.who.int/nmh/events/2014/backgrounder-e-cigarettes/en/. Accessed September 14, 2014 